\title{
USE OF COTYLEDON ORBICULATA L. IN TREATMENT OF PLANTAR WART (VERRUCA PLANTARIS)
}

\author{
BY \\ THEODORE JAMES \\ From Pinelands, The Cape of Good Hope, South Africa \\ (RECEIVED FOR PUbLICATION AUgUST 13, 1962)
}

The plantar wart (verruca plantaris) by its very position is crippling, and removal is desirable because of the ambulatory pain. However, two authors Coles (1958) and Churney (1961), have given much thought to the management of the plantar wart, and their conclusions are diametrically opposed. Coles (1958) states that the treatment of plantar warts in schoolchildren should be radical, in the form of diathermy under general anaesthesia. Most practising paediatricians would not accept this. Churney (1961) says that 'plantar warts should seldom be removed because of the poor results and frequent disability following this procedure. Peeling agents have been used but are of questionable value. They are also dangerous to use in children. Doughnut dressings to relieve pressure on the wart can be used over a period of several months.'

Children are, perhaps, more liable to acquire plantar warts, and it is most desirable that any form of treatment for this painful skin lesion should not itself be pain-producing and certainly not be more painful than the presence of the wart itself. Agents like glacial acetic acid or trichloracetic acid, applied daily to the surface of the wart after the overlying callous-like epidermis has been removed by softening and peeling, if necessary, have been used. This is a repetitive procedure which is tedious, there is no certainty that it will be successful, and it is not without some pain. But in the past nine years I have been using the Cotyledon orbiculata $\mathrm{L}$. which I found growing on a rockery in my garden. In Medicinal and Poisonous Plants of Southern Africa (Watt and Breyer-Brandwijk, 1934) there is an artist's reproduction in colour of the plant which is reproduced here in black and white (Figure). The information given in the book about this plant had, then, an added interest, and its use by the more primitive inhabitants of this country for the treatment of corns (sic) induced me to attempt its use in the treatment of the plantar wart.

\section{Method of Treatment}

The thick succulent leaf is put in an oven where its temperature is brought to about $200^{2} \mathrm{~F}$. When it is removed from the oven the thin surface layer of the slightly concave side of the leaf is removed, or if the leaf is unusually thick it may be bisected down its length, and the raw wet surface thus exposed is placed immediately over the wart which needs no preliminary preparation. The leaf is kept in position over the wart by an occlusive bandage of non-porous 'elastoplast' wrapped two or three times round the foot to ensure that the leaf-dressing is kept in place. This occlusive type of dressing of 'elastoplast' precludes evaporation of the leaf juice. This application is left in position for at least two weeks; at the end of three weeks it should be removed. Only once or twice has the treatment had to be repeated, and then it was for wart roots that were deep.

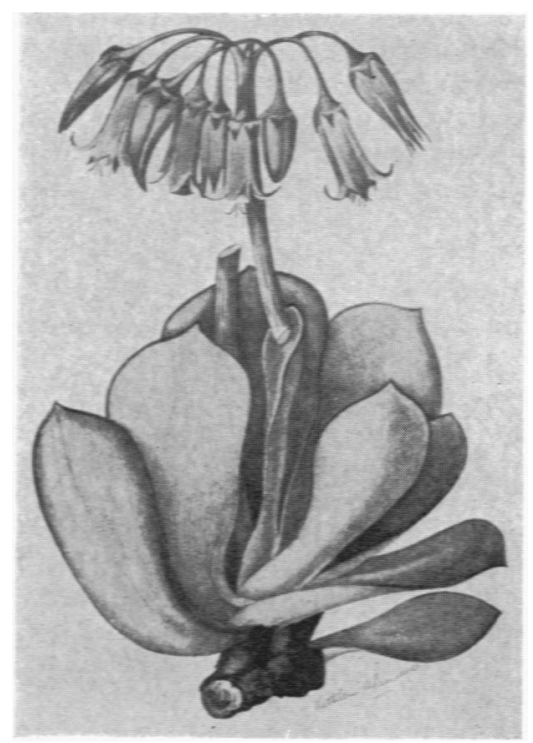

Figure.-Cotyledon orbiculata L. Reproduced by kind permission of the Editor of Government Publications, Union of South Africa, from Memoir IX of the Botanical Survey of South Africa. 
A remarkable fact about this application is the almost immediate soothing and analgesic effect. When the dressing of cotyledon is removed, the calloused skin with its in-lying and underlying wart and roots will come away.

\section{Discussion}

The illustration of the plant (Figure) is a blackand-white rendering of Kathleen A. Lansdale's original colour drawing of Cotyledon orbiculata L., but it shows clearly the distinctive features of the plant except for the colours. The flower is red and the leaves a grey-green. It is a genus of the family Crassulaceae, and in this multilingual land it goes by many names: Pig's ear, Honde-oor, Varkens-ore, Konterie, Oorlamsplakkie, Phewula, Seredile, inTelezi; it has been used extensively in South Africa. The native Xosas use the warmed leaf juice as ear drops for ear-ache, and also for toothache. But the plant is poisonous. Kamerman (1926) isolated from the fresh leaves cotyledontoxin, an amorphous, slightly bitter, colourless substance which he placed in the picrotoxin group, and which is soluble in water, alcohol and ether.

The cotyledontoxin depresses sensation on local application and depresses, apparently, the central nervous system when it is taken orally, for it produces a complete paralysis in animals which have eaten it (krimpsiekte). It is noteworthy that the toxic principle cannot be recovered from the leaf juice. Both Kamerman (1926) and Steyn (1929) found the toxicity of the plant to vary with its locality of growth and the time of its collection. Steyn records that plants growing in the Magaliesberg region are three times as toxic as those growing at Onderstepoort, and it was proved that heavy clay soil could produce a plant with four times the toxicity of a plant grown in sandy soil. Steyn was able to show that young, medium-sized or old leaves of the same plant did not vary in their toxicity and that the flowers were twice as toxic as the leaf.

This brief mention of some of the properties of the plant is made to give some theoretical support to the manner of the plant's therapeutic working. In the case of the plantar wart it is suggested that the property that depresses local sensation depresses the sensation of pain nerve-endings in the skin to a degree that brings about the remarkable and rapid relief from ambulatory pain once the dressing is in position. It is possible that this same property which anaesthetizes locally, or perhaps, another toxic property, is the one that destroys the wart.

\section{Summary}

The advantages of the use of a herbal remedy for the treatment of the plantar wart are indicated and a method of treatment is described. A hint with regard to a possible pharmacological basis for the therapeutic use of Cotyledon orbiculata $\mathrm{L}$. is given in the discussion. Because it is a plant that flourishes in the warm or hot, dry and exposed places in the more temperate parts of the Old World, as well as in the New World and other continents, it is hoped that it will become more widely used.

\section{REFERENCES}

Churney, A. M. (1961). Moles, warts and birthmarks. Pediat. Clin. N. Amer., 8, 249

Coles, R. B. (1958). Virus warts in school children. Publ. H/th (Lond.), 71, 371.

Kamerman, P. (1926). The toxicity of the genus cotyledon, the cause of the disease krimpsiekte. S. Afr. J. Sci., 23, 185.

Steyn, D. G. (1929). Recent Investigations into the Toxicity of Known and Unknown Poisonous Plants in the Union of South Africa. Fifteenth Report, Director of Veterinary Services, Anion of South Africa pp $777-803$.

Watt, J. M. and Breyer-Brandwijk, M. G. (1934). The Medicinal and Poisonous Plants of Southern Africa. Livingstone, Edinburgh. 